\title{
КОНЬЮГАТЫ ПРИРОДНЫХ ХЛОРИНОВ \\ С ТЕТРААЗАМАКРОЦИКЛАМИ КАК ПЛАТФОРМА ДЛЯ СОЗДАНИЯ АНТИМИКРОБНЫХ И ПРОТИВООПУХОЛЕВЫХ ПРЕПАРАТОВ
}

\author{
М.К. Федотова', Е.П. Агеева', Е.И. Винокурова', В.И. Брегадзе², \\ М.А. Грин' \\ ${ }^{1}$ Институт тонких химических технологий им. М.В. Ломоносова, \\ ФГБОУ ВО «МИРЭА - Российский технологический университет», \\ 119573, Россия, Москва, пр-т Вернадского, 86. \\ ${ }^{2}$ ИНЭОС им. А.Н. Несмеянова РАН, \\ 119991, Россия, Москва, ул. Вавилова, 28.
}

DOI: 10.19163/MedChemRussia2021-2021-375

e-mail:mk.khrenova@gmail.com

Разработка универсальной платформы на основе природных хлоринов с азотсодержащими фрагментами позволяет реализовывать направленный синтез фармакологически активных соединений для различных биомедицинских применений. Природные хлорины являются хорошо известными фотосенсибилизаторами, при облучении которых реализуется генерация активных форм кислорода и наблюдается цитотоксический и антимикробный эффекты. Присоединение борных полиэдров к молекуле пигмента обеспечивает создание перспективных тераностических агентов за счет адресной доставки в опухоль борного кластера, визуализации границ опухоли и бинарного воздействия на нее методами фотодинамической и бор-нейтронозахватной терапии.

Конъюгация тетраазамакроциклов с природными хлоринами реализуется как за счет прямого раскрытия циклопентанонового фрагмента в молекулах феофорбида а и бактериофеофорбида $а$, так и путем образования иминов с ацетильной группой пиррола А. Использование тетраазамакроциклов (циклен - 1,4,7,10-тетраазациклододекан и циклам - 1,4,8,11-тетраазациклотетрадекан) обеспечивает локализацию нескольких биоактивных молекул на периферии макроцикла. Высокая концентрация атомов бора в опухолевом очаге за счет присоединения до трех борных кластеров к циклену необходима для реализации терапевтического эффекта (20 мкг ${ }^{10} \mathrm{~B} / г$ опухоли). В данной работе использовались диоксониевые и нитриливые производные бис(1,2-дикарболлид) кобальта.

Работа выполнена при финансовой поддержке гранта РФФИ (№19-03-00255). 